\title{
SOSIALISASI KEBIJAKAN PENGELOLAAN DANA DESA TAHUN 2018 DI GAMPONG SUAK RAYA KECAMATAN JOHAN PAHLAWAN KABUPATEN ACEH BARAT PROVINSI ACEH
}

\author{
Zainal Putra \\ Fakultas Ekonomi, Universitas Teuku Umar \\ Email : zainalputra@utu.ac.id
}

\begin{abstract}
ABSTRAK
Sesungguhnya banyak aturan atau kebijakan yang harus dipahami oleh keuchik selaku kepala pemerintahan desa beserta aparatur pemerintah gampong lainnya selaku pengelola dana desa. Kebijakan tersebut sangat beragam dan terus berubah sepanjang waktu. Mulai dari UU, Peraturan Menteri Dalam Negeri, Peraturan Menteri Desa, Peraturan Menteri Keuangan, Peraturan Kepala LKPP, Peraturan Bupati, hingga petunjuk teknis yang diterbitkan oleh Direktorat terkait. Sebagaimana diketahui bahwa aparatur pemerintah desa kebanyakan memiliki tingkat pendidikan yang rendah, sehingga dapatlah dimaklumi mereka tidak menguasai dan tidak dapat mengikuti sepenuhnya terkait kebijakan dana desa yang terus berubah sepanjang waktu. Sangat disayangkan nantinya jikalau penggunaan dana desa ditemukan melanggar dari aturan yang telah ditetapkan pemerintah, maka konsekuensi harus ditanggung mutlak oleh aparatur pemerintah desa itu sendiri selaku pengelola dana desa. Oleh Karena itu kami dari Fakultas Ekonomi Universitas Teuku Umar, telah melakukan sosialisasi terkait kebijakan pengelolaan dana desa tahun 2018 di Gampong Suak Raya Kecamatan Johan Pahlawan Kabupaten Aceh Barat Provinsi Aceh, yang dihadiri oleh sebanyak 20 (dua puluh) orang masyarakat Gampong Suak Raya, terdiri dari aparatur pemerintah gampong, unsur Tuha Peut, tokoh pemuda dan tokoh perempuan setempat. Dengan adanya kegiatan sosialisasi tersebut diharapkan aparatur pemerintah desa tidak melakukan penyimpangan dalam pengelolaan dana desa, sehingga dapat terhindar dari masalah hukum dikemudian hari. Selain itu kegiatan ini juga telah memberikan pemahaman yang mendalam kepada masyarakat gampong mengenai dana desa di gampong mereka.
\end{abstract}

Kata Kunci : Sosialisasi Kebijakan Dana Desa, Gampong Suak Raya

\begin{abstract}
Indeed many rules or policies should be understood by the keuchik as head of village administration and other government officials of the gampong as the village fund manager. The policy is very diverse and constantly changing over time. Starting from the Law, the Regulation of the Minister of Home Affairs, the Regulation of the Minister of Finance, the Regulation of the Minister of Finance, the Regulation of the Head of LKPP, the Regent's Regulation, to the technical instructions issued by the relevant Directorate. As it is known that most of the village government officials have low levels of education, it is understandable that they have no control and can not fully follow the village fund policies that are changing over time. It is unfortunate later if the use of village funds found to violate the rules set by the government, then the consequences must be borne by the apparatus of the village government itself as the manager of village funds. Therefore we are from the Faculty of Economics Teuku Umar University,
\end{abstract}


has conducted socialization related to the policy of village fund management in 2018 in Gampong Suak Raya, Johan Pahlawan District, Aceh Barat District, Aceh Province, which was attended by 20 (twenty) of Gampong Suak Raya community, from the gampong government apparatur, elements of Tuha Peut, youth leaders and local women figures. With the socialization activities is expected that the village government officials do not make irregularities in the management of village funds, so it can be protected from legal problems in the future. In addition, this activity has also provided a deep understanding to the gampong community regarding village funds in their villages.

Keywords : Socialization of Village Funds Policy, Gampong Suak Raya

\section{PENDAHULUAN}

Pemerintah Republik Indonesia secara resmi menganggarkan dana desa dalam Anggaran Pendapatan dan Belanja Negara (APBN) mulai tahun 2015, yakni berdasarkan Peraturan Presiden RI Nomor 36 Tahun 2015 tentang Perubahan atas Undang Undang Nomor 27 Tahun 2014 tentang APBN Tahun Anggaran 2015. Di tahun pertama pengalokasian dana desa tersebut (tahun 2015), pemerintah telah mengucurkan dana desa sebesar Rp20.766.200.000.000,-. Jumlah tersebut merupakan $1,047 \%$ dari total anggaran belanja negara tahun 2015 sebesar Rp1.984.149.714.865.000,-Terdapat sebanyak 74.754 desa diseluruh Indonesia. Apabila dibagi rata, maka setiap desa mendapat alokasi dana pada tahun 2015 sebesar Rp277.793.830,-.

Dalam konteks yang lebih sempit, tidak terkecuali Gampong Suak

Raya Kecamatan Johan Pahlawan Kabupaten Aceh Barat juga mendapatkan kucuran dana desa dari pemerintah. Dari data yang penulis dapatkan, diperoleh informasi bahwa dari tahun 2016 - 2018, Gampong Suak Raya ini telah mendapatkan aliran dana desa dari pemerintah sebesar Rp2.380.983.000,- $\quad$ sebagaimana disajikan dalam tabel di bawah ini.

Tabel 1.

Data Penerimaan Dana Desa dan Alokasi Dana Desa Gampong Suak Raya Kecamatan Johan Pahlawan Kabupaten Aceh Barat, Periode 2016 - 2018

\begin{tabular}{|c|c|c|c|c|}
\hline Uraian & $\begin{array}{l}2016 \\
\text { (Rp) }\end{array}$ & $\begin{array}{l}2017 \\
\text { (Rp) }\end{array}$ & $\begin{array}{l}2018 \\
\text { (Rp) }\end{array}$ & $\begin{array}{c}\text { Jumlah } \\
\text { (Rp) }\end{array}$ \\
\hline Dana Desa & 585.459 .000 & 745.415 .000 & 662.503 .000 & 1.993 .377 .000 \\
\hline Alokasi Dana Desa & - & 195.601 .700 & 192.004 .300 & 387.606 .000 \\
\hline
\end{tabular}




\begin{abstract}
$\begin{array}{lllll}\text { Jumlah } & \mathbf{5 8 5 . 4 5 9 . 0 0 0} & \mathbf{9 4 1 . 0 1 6 . 7 0 0} & \mathbf{8 5 4 . 5 0 7 . 3 0 0} & \mathbf{2 . 3 8 0 . 9 8 3 . 0 0 0}\end{array}$
Sumber: Peraturan Bupati Aceh Barat Nomor 45 Tahun 2015 tentang Penetapan Besaran Dana Desa TA 2016, Peraturan Bupati Aceh Barat Nomor 88 Tahun 2016 tentang Penetapan Besaran Dana Desa 2017, Peraturan Bupati Aceh Barat Nomor 87 Tahun 2016 tentang Penetapan Besaran Alokasi Dana Desa TA 2017, Peraturan Bupati Aceh Barat Nomor 90 Tahun 2017 tentang Penetapan Besaran Dana Desa 2018 dan Peraturan Bupati Aceh Barat Nomor 89 Tahun 2017 tentang Penetapan Besaran Alokasi Dana Desa 2018.
\end{abstract}

Dana desa dikelola oleh aparatur pemerintahan desa dengan struktur pengelola keuangan desa sebagaimana dijelaskan dalam Peraturan Menteri Dalam Negeri Nomor 113 Tahun 2014 tentang Pengelolaan Keuangan Desa, meliputi:

a. Kepala Desa selaku pemegang kekuasaan pengelola keuangan desa dan mewakili pemerintah desa dalam kepemilikan kekayaan milik desa yang dipisahkan.

b. Sekretaris Desa, bertindak selaku koordinator pelaksana teknis pengelolaan keuangan desa (TPKD).

c. Kasi bertindak selaku pelaksana kegiatan sesuai bidangnya.

d. Bendahara, dijabat oleh staf pada urusan keuangan.

$$
\text { Dalam Pasal } 5 \text { Peraturan }
$$

Menteri Desa, Pembangunan Daerah Tertinggal dan Transmigrasi Nomor 19 Tahun 2017 tentang Penetapan Prioritas Penggunaan Dana Desa Tahun 2018, dijelaskan bahwa dana desa digunakan untuk membiayai pembangunan desa yang ditujukan untuk meningkatkan kesejahteraan masyarakat desa, peningkatan kualitas hidup manusia serta penanggulangan kemiskinan dengan prioritas penggunaan dana desa diarahkan untuk pelaksanaan program dan kegiatan pembangunan desa, yang meliputi antara lain:

a. Pengadaan, pembangunan, pengembangan, dan pemeliharaan sarana prasarana dasar untuk pemenuhan kebutuhan:

1. lingkungan pemukiman;

2. transportasi;

3. energi; dan

4. informasi dan komunikasi.

b. Pengadaan, pembangunan, pengembangan, dan pemeliharaan sarana prasarana pelayanan sosial dasar untuk pemenuhan kebutuhan:

1. kesehatan masyarakat; dan

2. pendidikan dan kebudayaan.

c. Pengadaan, pembangunan, pengembangan, dan pemeliharaan sarana prasarana ekonomi untuk 
mewujudkan Lumbung Ekonomi Desa, meliputi:

1. Usaha ekonomi pertanian berskala produktif untuk ketahanan pangan;

2. Usaha ekonomi pertanian berskala produktif meliputi aspek produksi, distribusi dan pemasaran yang difokuskan kepada pembentukan dan pengembangan produk unggulan desa dan/atau produk unggulan kawasan perdesaan; dan

3. Usaha ekonomi non pertanian berskala produktif meliputi aspek produksi, distribusi dan pemasaran yang difokuskan kepada pembentukan dan pengembangan produk unggulan desa dan/atau produk unggulan kawasan perdesaan.

d. Pengadaan, pembangunan, pengembangan, dan pemeliharaan sarana prasarana lingkungan untuk pemenuhan kebutuhan:

1. kesiapsiagaan menghadapi bencana alam;

2. penanganan bencana alam; dan

3. pelestarian lingkungan hidup.

Dapat kami informasikan bahwa sesungguhnya cukup banyak aturan atau kebijakan yang harus dipahami oleh keuchik selaku kepala pemerintahan desa. Kebijakan terkait dengan dana desa ini sangat beragam dan terus berubah sepanjang waktu. Mulai dari UU, Peraturan Menteri Dalam Negeri, Peraturan Menteri Desa, Peraturan Menteri Keuangan, Peraturan Kepala LKPP, Peraturan Bupati, hingga Petunjuk Teknis yang diterbitkan oleh Direktorat terkait.

Sebagaimana diketahui bahwa aparatur pemerintah desa kebanyakan memiliki tingkat pendidikan yang rendah, sehingga dapatlah dimaklumi mereka tidak menguasai dan tidak dapat mengikuti sepenuhnya terkait kebijakan dana desa yang terus berubah sepanjang waktu. Sangat disayangkan nantinya jikalau penggunaan dana desa ditemukan melanggar dari aturan yang telah ditetapkan pemerintah, maka konsekuensi harus ditanggung mutlak oleh aparatur pemerintah desa itu sendiri selaku pengelola dana desa.

Atas dasar itulah kami dari Fakultas Ekonomi Universitas Teuku Umar, merasa terpanggil untuk melakukan pencerahan dan peningkatan kapasitas kepada aparatur pemerintah desa dalam hal peningkatan pemahaman atas kebijakan pengelolaan dana desa. Oleh karena itu kami kemas kegiatan ini 
dalam bentuk pengabdian kepada masyarakat dengan tema "Sosialisasi Kebijakan Pengelolaan Dana Desa TA 2018 di Gampong Suak Raya Kecamatan Johan Pahlawan Kabupaten Aceh Barat".

\section{Permasalahan Mitra}

Dari hasil pengamatan yang kami lakukan diketahui bahwa selama ini tingkat pemahaman aparatur pemerintah desa atas kebijakan pengelolaan dana desa masih rendah. Hal tersebut dikarenakan peraturan terkait dana desa ini cukup beragam dan terus berubah sepanjang waktu. Ditambah lagi dengan tingkat pendidikan aparatur pemerintah desa yang masih rendah, menjadi kendala tersendiri mereka.

\section{Solusi yang Ditawarkan}

Melalui kegiatan pengabdian kepada masyarakat ini, kami menawarkan solusi kepada mitra sebagai berikut:

- Melakukan sosialisasi kebijakan pengelolaan dana Desa tahun 2018 di Gampong Suak Raya Kecamatan Johan Pahlawan Kabupaten Aceh Barat Provinsi Aceh.

Dengan demikian diharapkan aparatur pemerintah desa dalam pengelolaan dana desa tidak akan menyimpang dari peraturan yang telah ditetapkan pemerintah, sehingga dapat terhindar dari masalah hukum dikemudian hari.

\section{METODE PELAKSANAAN}

Direncanakan sasaran program pengabdian kepada masyarakat ini adalah sebanyak 10 sampai dengan 20 orang unsur pemerintahan desa termasuk tokoh atau mayarakat desa setempat, yaitu di Gampong Suak Raya Kecamatan Johan Pahlawan Kabupaten Aceh Barat.

Metode pelaksanaan kegiatan pengabdian kepada masyarakat ini dilakukan dengan memberikan sosialisasi terkait dengan beragam kebijakan pengelolaan dana desa tahun 2018.

Kegiatan seperti ini dirasakan sangat perlu bagi aparatur pemerintahan desa dan juga untuk meningkatkan pemahaman dan keterampilan aparatur pemerintah desa dalam pengelolaan dana desa yang akuntabel. Adapun bahan pembelajaran yang akan diberikan sebagaimana disajikan dalam tabel berikut. 
Tabel 2.

Bahan pembelajaran sosialisasi kebijakan pengelolaan dana desa

Di Gampong Suak Raya Kecamatan Johan Pahlawan Kabupaten Aceh Barat

\begin{tabular}{|c|c|c|}
\hline & Uraian & Luaran \\
\hline Materi & $\begin{array}{l}\text { Sosialisasi kebijakan pengelolaan dana desa } \\
\text { TA } 2018 \\
\text { Referensi: } \\
\text { - Peraturan Pemerintah Nomor } 43 \text { Tahun } \\
2014 \text { tentang Peraturan Pelaksanaan } \\
\text { Undang-Undang Nomor } 6 \text { Tahun } 2014 \\
\text { tentang Desa. } \\
\text { - Peraturan Menteri Desa, Pembangunan } \\
\text { Daerah Tertinggal dan Transmigrasi } \\
\text { Nomor } 19 \text { Tahun } 2017 \text { tentang Penetapan } \\
\text { Prioritas Penggunaan Dana Desa Tahun } \\
2018 . \\
\text { - Peraturan Menteri Dalam Negeri Nomor } \\
113 \text { Tahun 2014 tentang Pengelolaan } \\
\text { Keuangan Desa. } \\
\text { - Peraturan Kepala LKPP Nomor } 13 \text { Tahun } \\
2013 \text { tentang Pedoman Tata Cara } \\
\text { Pengadaan Barang/Jasa di Desa. } \\
\text { - Peraturan Kepala LKPP Nomor } 22 \text { Tahun } \\
2015 \text { tentang Perubahan atas Peraturan } \\
\text { Kepala LKPP Nomor 13 Tahun } 2013 . \\
\text { tentang Pedoman Tata Cara Pengadaan } \\
\text { Barang/Jasa di Desa. } \\
\text { - Peraturan Bupati Aceh Barat Nomor } 11 \\
\text { Tahun 2017 tentang Standar Biaya Umum } \\
\text { Bagi Gampong Dalam Kabupaten Aceh } \\
\text { Barat. }\end{array}$ & $\begin{array}{l}\text { 1. Terjadi peningkatan } \\
\text { pemahaman aparatur } \\
\text { pemerintah desa atas } \\
\text { beragam kebijakan } \\
\text { pengelolaan dana desa. } \\
\text { 2. Pelaksanaan dana desa } \\
\text { tidak menyimpang dari } \\
\text { ketentuan yang } \\
\text { ditetapkan pemerintah. }\end{array}$ \\
\hline
\end{tabular}

\section{HASIL DAN PEMBAHASAN}

Kegiatan "Sosialisasi Kebijakan Pengelolaan Dana Desa Tahun 2018 di Gampong Suak Raya Kecamatan Johan Pahlawan Kabupaten Aceh Barat Provinsi Aceh" telah dilaksanakan pada hari Sabtu, tanggal 05 Mei 2018 yang bertempat di kantor keuchik gampong setempat. Sasaran program adalah aparatur pemerintah Gampong Suak Raya, Tuha Peut, tokoh masyarakat dan tokoh pemuda gampong tersebut.

Namun demikian, secara keseluruhan kegiatan ini memakan waktu selama 21 (dua puluh satu) hari dengan penjelasan dapat dilihat pada tabel di bawah ini. 
Tabel 3.

Jadwal Pelaksanaan Kegiatan

\begin{tabular}{|c|c|c|c|c|c|c|}
\hline \multirow{3}{*}{ No. } & \multirow{3}{*}{ Kegiatan } & \multicolumn{5}{|c|}{ Tanggal (April - Mei 2018) } \\
\hline & & \multirow{2}{*}{$\begin{array}{c}\text { April } \\
18 \mathrm{~s} / \mathrm{d} 25\end{array}$} & \multirow{2}{*}{26 April s/d 4 Mei } & \multicolumn{3}{|c|}{ Mei } \\
\hline & & & & 5 & 7 & 8 \\
\hline 1. & Perencanaan & & & & & \\
\hline 2. & Komunikasi dan & & & & & \\
\hline & koordinasi dengan mitra & & & & & \\
\hline 3. & Pelaksanaan program & & & & & \\
\hline 4. & Administrasi dan & & & & & \\
\hline & dokumentasi & & & & & \\
\hline 5. & Finalisasi laporan & & & & & \\
\hline
\end{tabular}

Adapun bahan pembelajaran pelatihan sebagaimana disajikan dalam yang diberikan pada saat pelaksanaan tabel berikut ini.

Tabel 4.

Bahan Pembelajaran pada Kegiatan Sosialisasi Kebijakan Pengelolaan

Dana Desa TA 2018 di Gampong Suak Raya

Kecamatan Johan Pahlawan Kabupaten Aceh Barat Provinsi Aceh

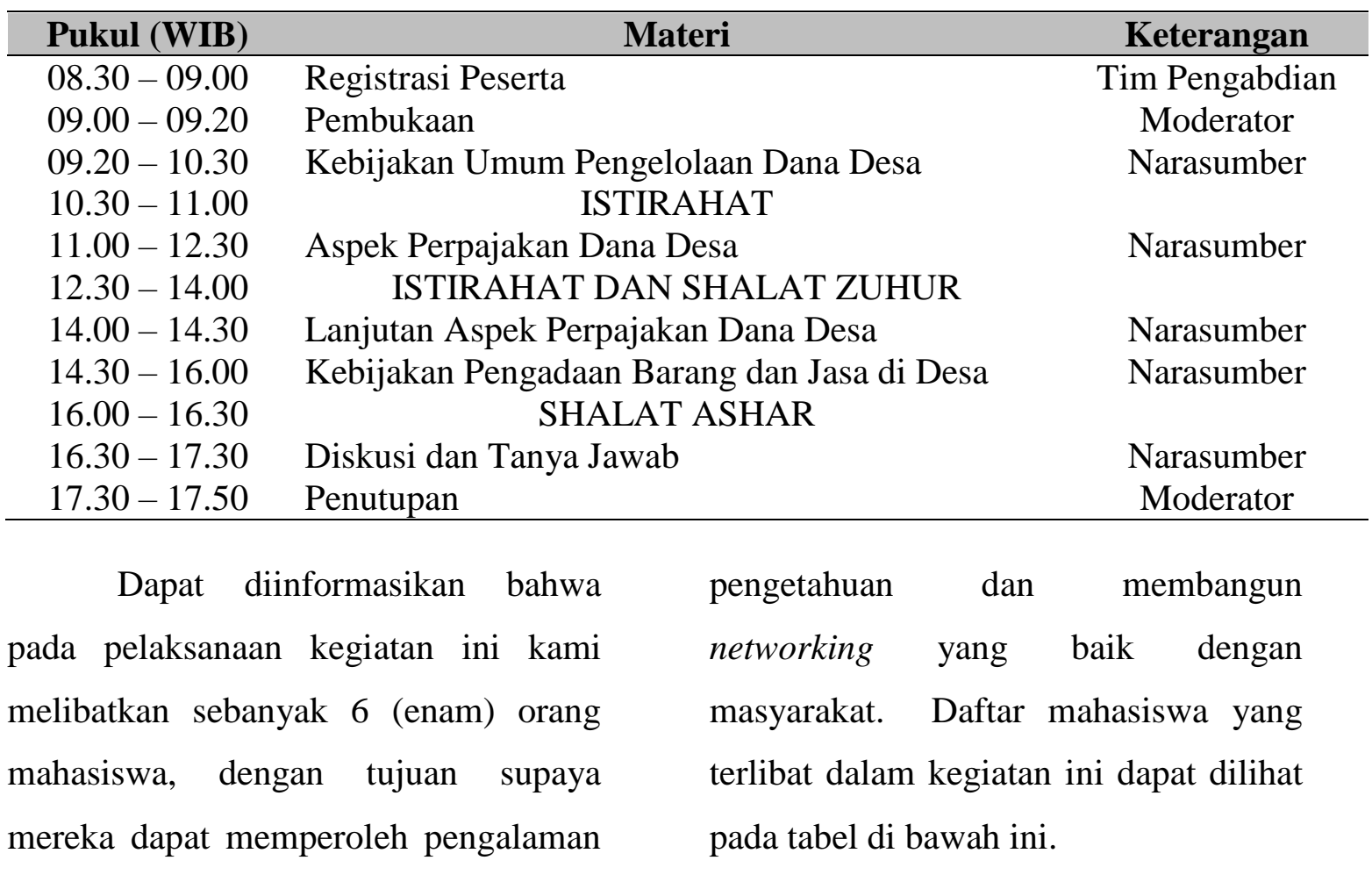

langsung di lapangan, menambah

Tabel 5.

Nama-Nama Mahasiswa yang Dilibatkan dalam Kegiatan Sosialisasi Kebijakan Pengelolaan 
Dana Desa TA 2018 di Gampong Suak Raya Kecamatan Johan Pahlawan Kabupaten Aceh Barat Provinsi Aceh

\begin{tabular}{clc}
\hline No. & \multicolumn{1}{c}{ Nama Mahasiswa } & Program Studi \\
\hline 1. & Agusuwantri & S1 Ekonomi Pembangunan \\
2. & M. Amar Akbar & S1 Ekonomi Pembangunan \\
3. & Rini Oktarina & S1 Ekonomi Pembangunan \\
4. & Aad Gunawan & S1 Manajemen \\
5. & Taufiq Qurrahman & S1 Manajemen \\
6. & Faisal & S1 Manajemen \\
\hline
\end{tabular}

Berdasarkan daftar hadir, Sabtu (05/05/18) adalah sebanyak 20 diperoleh informasi jumlah peserta yang (dua puluh) orang, seperti disajikan hadir pada hari pelaksanaan kegiatan, dalam tabel di bawah ini.

Tabel 6.

Nama-Nama Peserta yang Hadir Mengikuti

Kegiatan Sosialisasi Kebijakan Pengelolaan Dana Desa TA 2018 di Gampong Suak Raya Kecamatan Johan Pahlawan

Kabupaten Aceh Barat Provinsi Aceh

\begin{tabular}{clc}
\hline No. & \multicolumn{1}{c}{ Nama } & Jabatan \\
\hline 1. & Zainuddin & Keuchik \\
2. & Jufri & Sekretaris Desa \\
3. & Bustamam & Ulee Jurong Kubah Pahlawan \\
4. & Zul Akman & Ulee Jurong TM Arief \\
5. & Said Suhermansyah & Kepala Urusan Pembangunan \\
6. & Marlinda & Kepala Urusan Pemerintahan \\
7. & Yul Asdar & Kepala Urusan Kesejahteraan Rakyat \\
8. & Eka Juliati & Bendahara Desa \\
9. & TA Hamid & Unsur Tuha Peut \\
10. & Muzakir & Unsur Tuha Peut \\
11. & Jamuri Ismail & Unsur Tuha Peut \\
12. & Cut Marwati & Ketua PKK \\
13. & Samsidar & Tokoh Wanita \\
14. & Rita Mairisa & Staf Administrasi Desa \\
15. & Irma Suryani & Kader Posyandu \\
16. & Nora Afrilita & Masyarakat \\
17. & Ferdiansyah & Operator Kantor Desa \\
18. & Safrida & Masyarakat \\
19. & Mawardi & Masyarakat \\
20. & Zafhuri & Masyarakat \\
\hline
\end{tabular}

Di akhir acara kami memintakan beberapa testimoni dari peserta pelatihan dan mahasiswa yang dilibatkan seperti disajikan dalam tabel 
di bawah ini. Hal ini diperlukan sebagai umpan balik atas pelaksanaan kegiatan dan untuk melihat dari sudut pandang masyarakat seberapa pentingnya

pelaksanaan kegiatan ini.

Tabel 7.

Beberapa Testimoni Terhadap Pelaksanaan Kegiatan Sosialisasi

Kebijakan Pengelolaan Dana Desa TA 2018 di Gampong Suak Raya

Kecamatan Johan Pahlawan Kabupaten Aceh Barat Provinsi Aceh

\begin{tabular}{|c|c|c|}
\hline No. & Nama & Testimoni \\
\hline 1. & $\begin{array}{l}\text { Zainuddin } \\
\text { (Keuchik Gampong Suak Raya) }\end{array}$ & $\begin{array}{lcrr}\text { Pelaksanaan } & \text { kegiatan } & \text { ini sangat } \\
\text { memuaskan dan dapat menambah } \\
\text { pemahaman peserta dalam } & \text { hal } \\
\text { pengelolaan dana desa. } & & \end{array}$ \\
\hline 2. & $\begin{array}{l}\text { Jufri } \\
\text { (Sekretaris Gampong Suak } \\
\text { Raya) }\end{array}$ & $\begin{array}{l}\text { Penjelasan narasumber terhadap } \\
\text { kebijakan pengelolaan dana desa sangat } \\
\text { jelas. Kegiatan serupa yang pernah } \\
\text { kami ikuti di Pemkab. Aceh Barat tidak } \\
\text { sejelas seperti hari ini. Kami berharap, } \\
\text { hendaknya narasumber dapat } \\
\text { memprogramkan lagi kegiatannya di } \\
\text { gampong kami. Kegiatan kali ini benar- } \\
\text { benar dapat menambah pengetahuan } \\
\text { bagi kami. }\end{array}$ \\
\hline 3. & $\begin{array}{l}\text { Said Hermansyah } \\
\text { (Kepala Urusan Pembangunan) }\end{array}$ & $\begin{array}{l}\text { Pelaksanaan kegiatan ini sangat } \\
\text { memuaskan peserta hari ini. Kami } \\
\text { mohon pada masa yang akan datang } \\
\text { narasumber dapat memprogramkan } \\
\text { kegiatan di tempat kami dengan tema } \\
\text { tata cara penyusunan dokumen - } \\
\text { dokumen gampong dan tentang } \\
\text { pelaporan keuangan gampong. }\end{array}$ \\
\hline 4. & $\begin{array}{l}\text { Eka Juliati } \\
\text { (Bendahara Gampong) }\end{array}$ & $\begin{array}{l}\text { Kami sangat mendukung pelaksanaan } \\
\text { kegiatan ini, sehingga ke depan kami } \\
\text { dapat mengelola lagi dana gampong } \\
\text { dengan lebih terarah lagi. }\end{array}$ \\
\hline 5. & $\begin{array}{l}\text { Rini Oktarina } \\
\text { (Mahasiswa Prodi S1 Ekonomi } \\
\text { Pembangunan) }\end{array}$ & $\begin{array}{l}\text { Kegiatan ini sangat menarik dan sangat } \\
\text { berguna bagi aparatur pemerintah } \\
\text { gampong dalam meningkatkan } \\
\text { pemahaman dalam pengelolaan dana } \\
\text { desa. Bagi kami mahasiswa kgiatan ini } \\
\text { dapat menambah pengalaman sekaligus } \\
\text { dapat membangun networking yang } \\
\text { baik dengan masyarakat gampong. }\end{array}$ \\
\hline
\end{tabular}


Adapun luaran yang dicapai atas pelaksanaan kegiatan sosialisasi kebijakan pengelolaan dana desa tahun 2018 di Gampong Suak Raya ini adalah:

a. Telah meningkatkan pengetahuan dan pemahaman masyarakat Gampong Suak Raya atas kebijakan pengelolaan dana desa (soft skill).

b. Telah meningkatkan kepercayaan masyarakat kepada aparatur pemerintah Gampong Suak Raya dalam pengelolaan dana desa.

\section{FOTO KEGIATAN}

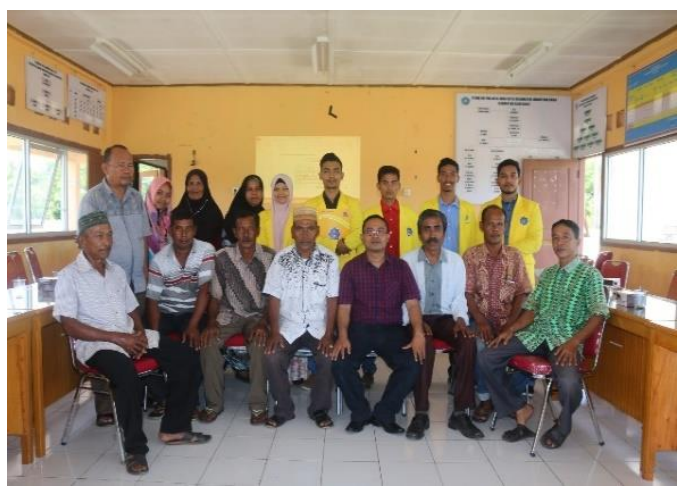

Gambar 1. Tim Pengabdian berfoto bersama dengan aparatur Pemerintah Gampong Suak Raya.

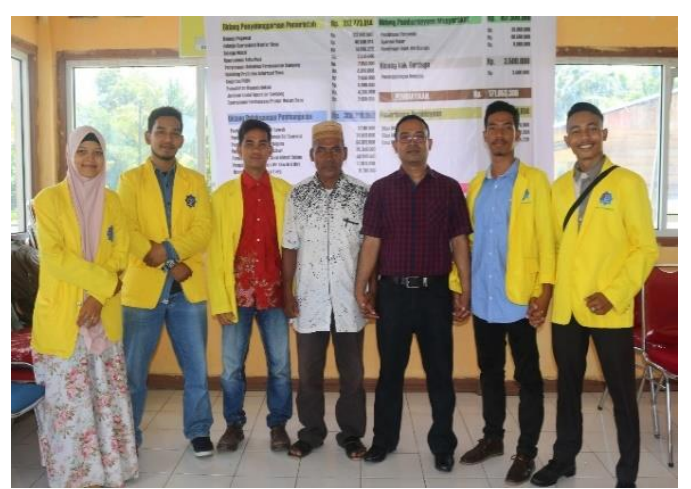

Gambar 2. Tim Pengabdian berfoto bersama dengan Keuchik Gampong Suak Raya, Zainuddin.

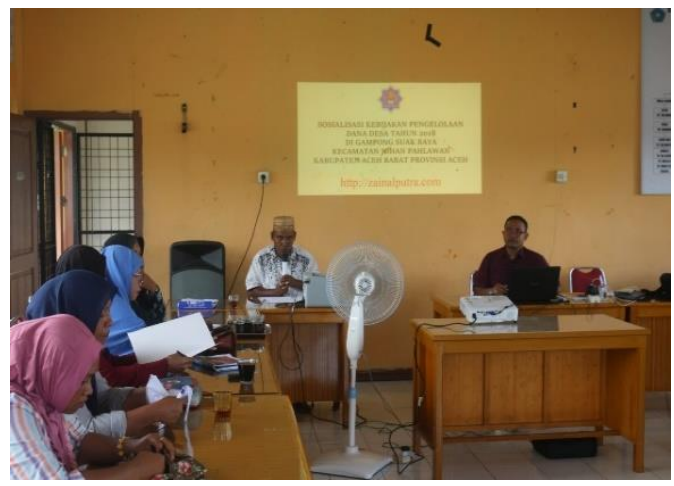

Gambar 3. Keuchik Gampong Suak Raya, Zainuddin sedang memberikan kata sambutan pada saat pembukaan acara.

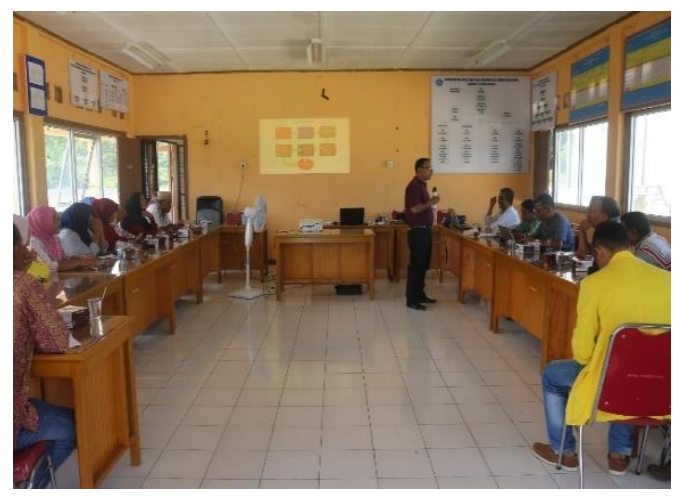

Gambar 4. Narasumber, Zainal Putra, SE, MM sedang memberikan pelatihan.

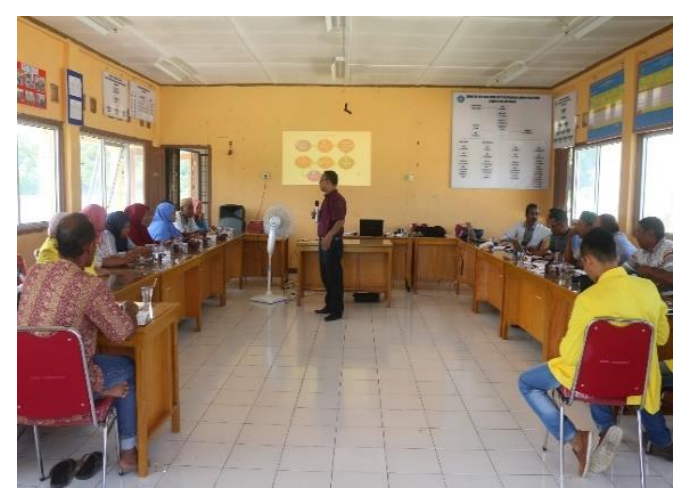

Gambar 5. Narasumber, Zainal Putra, SE, MM sedang memberikan pelatihan. 


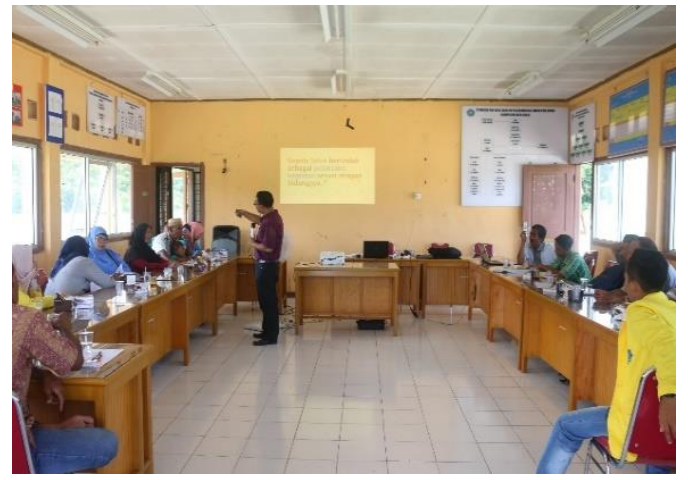

Gambar 6. Narasumber, Zainal Putra, SE, MM sedang memberikan pelatihan.

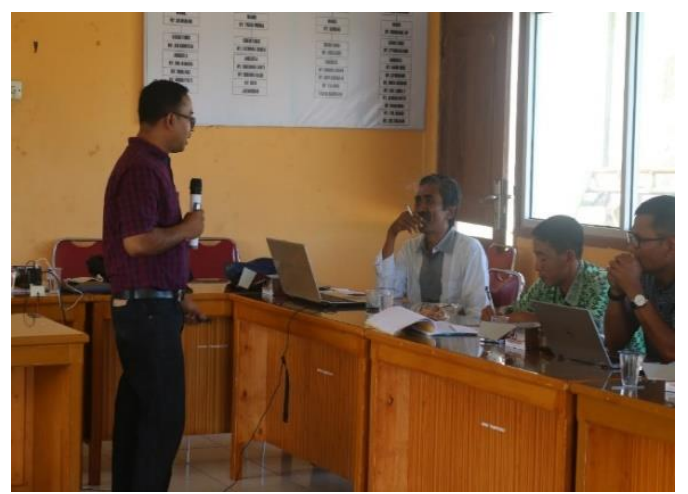

Gambar 7. Sekretaris Gampong Suak Raya, Jufri, SE sedang melakukan diskusi / tanya jawab dengan narasumber, Zainal Putra, SE, MM.

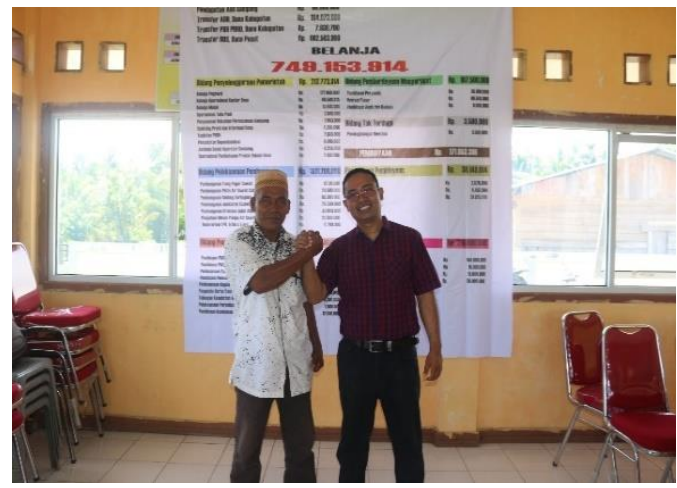

Gambar 8. Keuchik Gampong Suak Raya, Zainuddin melakukan salam komando dengan dengan narasumber, Zainal Putra, SE, MM.

\section{KESIMPULAN DAN SARAN}

- Kesimpulan

Alhamdulillah, berkat dukungan semua pihak kegiatan sosialisasi kebijakan pengelolaan dana desa TA 2018 di Gampong Suak Raya berjalan dengan lancar tanpa halangan apapun. Semua peserta antusias mengikuti acara hingga selesai dan merasakan manfaat kegiatan ini dalam rangka pengelolaan dana desa yang lebih terarah pada masa yang akan datang.

Patut dimaklumi bahwa kegiatan semacam ini adalah salah satu langkah nyata / kontribusi langsung pihak Fakultas Ekonomi UTU kepada masyarakat. Kita perlu membuktikan kepada masyarakat bahwa kampus UTU bukanlah menara gading yang berdiri megah sendiri, ekslusif dan hanya berkutat dengan pengajaran dan penelitian yang tidak berdampak kepada masyarakat. Melalui kegiatan ini, sekarang sudah terjawab bahwa UTU, khususnya sivitas akademik Fakultas Ekonomi telah hadir ditengah-tengah masyarakat dalam rangka membagi pengetahuan terkait pengelolaan dana desa.

\section{- Saran}

$$
\text { Kegiatan serupa dapat }
$$

dilaksanakan kembali dengan sasaran 
gampong yang berbeda peserta yang lebih banyak/luas, dan dengan topik yang sama, mengingat banyak aparatur pemerintah gampong, unsur Tuha Peut dan tokoh masyarakat belum memahami dengan baik terkait kebijakan pengeloaan dana desa yang sangat beragam ini.

Namun dari pihak manajemen Universitas Teuku Umar hendaknya dapat mengalokasikan dan menyalurkan dana pengabdian kepada tim kami ke depannya, sehingga kendala pendanaan yang kami hadapi dapat teratasi.

\section{DAFTAR PUSTAKA}

Peraturan Presiden Nomor 36 Tahun 2015 tentang Perubahan atas Undang Undang Nomor 27 Tahun 2014 tentang APBN Tahun Anggaran 2015

Peraturan Pemerintah Nomor 43 Tahun 2014 tentang Peraturan Pelaksanaan Undang-Undang Nomor 6 Tahun 2014 tentang Desa

Peraturan Menteri Desa, Pembangunan Daerah Tertinggal dan Transmigrasi Nomor 19 Tahun 2017 tentang Penetapan Prioritas Penggunaan Dana Desa Tahun 2018
Peraturan Menteri Dalam Negeri Nomor 113 Tahun 2014 tentang Pengelolaan Keuangan Desa

Peraturan Kepala LKPP Nomor 13 Tahun 2013 tentang Pedoman Tata Cara Pengadaan Barang/Jasa di Desa

Peraturan Kepala LKPP Nomor 22 Tahun 2015 tentang Perubahan atas Peraturan Kepala LKPP Nomor 13 Tahun 2013 tentang Pedoman Tata Cara Pengadaan Barang/Jasa di Desa

Peraturan Bupati Aceh Barat Nomor 45 Tahun 2015 tentang Penetapan Besaran Dana Desa TA 2016

Peraturan Bupati Aceh Barat Nomor 88 Tahun 2016 tentang Penetapan Besaran Dana Desa 2017

Peraturan Bupati Aceh Barat Nomor 87 Tahun 2016 tentang Penetapan Besaran Alokasi Dana Desa TA 2017

Peraturan Bupati Aceh Barat Nomor 11 Tahun 2017 tentang Standar Biaya Umum Bagi Gampong Dalam Kabupaten Aceh Barat

Peraturan Bupati Aceh Barat Nomor 89 Tahun 2017 tentang Penetapan Besaran Alokasi Dana Desa 2018

Peraturan Bupati Aceh Barat Nomor 90 Tahun 2017 tentang Penetapan Besaran Dana Desa 2018 